\title{
MODERN BIOMASS CONVERSION TECHNOLOGIES
}

\author{
ANDRE FAAIJ \\ Copernicus Institute, Utrecht University, Heidelberglaan 2, 3584 CS, Utrecht, The Netherlands \\ (*Author for correspondence: E-mail: A.Faaij@chem.uu.nl)
}

(Received 9 February 2005; accepted in final form 18 June 2005)

\begin{abstract}
This article gives an overview of the state-of-the-art of key biomass conversion technologies currently deployed and technologies that may play a key role in the future, including possible linkage to $\mathrm{CO}_{2}$ capture and sequestration technology (CCS). In doing so, special attention is paid to production of biofuels for the transport sector, because this is likely to become the key emerging market for large-scale sustainable biomass use. Although the actual role of bio-energy will depend on its competitiveness with fossil fuels and on agricultural policies worldwide, it seems realistic to expect that the current contribution of bio-energy of 40-55 EJ per year will increase considerably. A range from 200 to $300 \mathrm{EJ}$ may be observed looking well into this century, making biomass a more important energy supply option than mineral oil today. A key issue for bio-energy is that its use should be modernized to fit into a sustainable development path. Especially promising are the production of electricity via advanced conversion concepts (i.e. gasification and state-of-the-art combustion and cofiring) and modern biomass derived fuels like methanol, hydrogen and ethanol from ligno-cellulosic biomass, which can reach competitive cost levels within 1-2 decades (partly depending on price developments with petroleum). Sugar cane based ethanol production already provides a competitive biofuel production system in tropical regions and further improvements are possible. Flexible energy systems, in which biomass and fossil fuels can be used in combination, could be the backbone for a low risk, low cost and low carbon emission energy supply system for large scale supply of fuels and power and providing a framework for the evolution of large scale biomass raw material supply systems. The gasification route offers special possibilities to combine this with low cost $\mathrm{CO}_{2}$ capture (and storage), resulting in concepts that are both flexible with respect to primary fuel input as well as product mix and with the possibility of achieving zero or even negative carbon emissions. Prolonged RD\&D efforts and biomass market development, consistent policy support and international collaboration are essential to achieve this.
\end{abstract}

Keywords: biomass conversion, combustion, gasification, hydrolysis, digestion, biofuels, electricity, carbon capture, storage

\section{Introduction - The Current and Potential Role for Modern Bio-Energy}

Current energy supplies in the world are dominated by fossil fuels (some $80 \%$ of the total use of over $400 \mathrm{EJ}$ per year). Nevertheless, about $10-15 \%$ (or $45 \pm 10 \mathrm{EJ}$ ) of this demand is covered by biomass resources, making biomass by far the most important renewable energy source used to date. On average, in the industrialized countries biomass contributes some $9-13 \%$ to the total energy supplies, but in developing countries the proportion is as high as a fifth to one third. In quite a number of countries biomass covers even over 50-90\% of the total energy demand. A large part of this biomass use is however non-commercial and used for cooking and space 
heating, generally by the poorer part of the population. This also explains why the contribution of biomass to the energy supply is not exactly known; non-commercial use is poorly mapped. In addition, some traditional use is not sustainable because it may deprive local soils of needed nutrients, cause indoor and outdoor pollution and result in poor health. It may also contribute to GHG emissions and affect ecosystems if biomass is taken for energy without replanting and other conservation management. Part of this use is commercial though, i.e. the household fuel wood in industrialized countries and bio-char ("charcoal") and firewood in urban and industrial areas in developing countries, but there are almost no data on the size of those markets. An estimated $9 \pm 6 \mathrm{EJ}$ is covered by this category.

Modern bio-energy (commercial energy production from biomass for industry, power generation or transport fuels) makes a lower, but still very significant contribution (some $7 \mathrm{EJ} / \mathrm{yr}$ in 2000), and this share is growing. It is estimated that end of the nineties, some $40 \mathrm{GWe}$ biomass based electricity production capacity was installed worldwide (good for $160 \mathrm{TWh} / \mathrm{year}$ ) and $200 \mathrm{GW}$ heat production capacity $(>700 \mathrm{TWh} /$ year). Total production of biofuels (mainly ethanol produced from sugar cane and surpluses of corn and cereals and to a far lesser extent bio-diesel from oil-seed crops) amounted some 18 billion litres per year. This equals about $0.5 \mathrm{EJ}$ as transport fuel (around 2000), but worldwide production of biofuels (especially bio-ethanol) is growing rapidly (Turkenburg et al. 2000).

The (technical) potential contribution of bio-energy to the future world's energy supply could be very large. In theory, energy farming on current agricultural land could, with projected technological progress, contribute over $800 \mathrm{EJ}$, without jeopardising the world's food supply. Organic wastes and residues could possibly supply another 40-170 EJ, with uncertain contributions from forest residues and potentially a very significant role for organic waste, especially when bio-materials are used on a larger scale. In total, the upper limit the of bio-energy potential could be over $1000 \mathrm{EJ}$ (per year). This is considerably more than the current global energy use of 400 EJ (Hoogwijk et al. 2003; Smeets et al. 2004).

Latin America, Sub-Saharan Africa and Eastern Europe clearly are promising regions, also Oceania and East and NE Asia jump out as potential biomass production areas on the longer term. The latter can in particular be explained by the projected demographic developments (declining population in China after 2020) and fast technological progress in agriculture, leading to substantial productivity increases.

These analyses also show that a large part of the technical potential for biomass production may be developed at low production costs in the range of $2 \mathrm{U} \$ / \mathrm{GJ}$ (Hoogwijk et al. 2004; Smeets et al. 2005).

Major transitions are however required to exploit this bio-energy potential. Especially improving agricultural efficiency in developing countries (i.e. increasing crop yields per hectare) is a key factor. It is still uncertain to what extent and how fast such transitions can be realized in different regions. Under less favourable conditions, the (regional) bio-energy potential(s) could be quite low. 
Also, it should be noted that technological developments (in conversion, as well as long distance biomass supply chains (i.e. comprising intercontinental transport of biomass derived energy carriers) can dramatically improve competitiveness and efficiency of bio-energy. Increased competitiveness is logically a driver to develop the production potentials of bio-energy. This article gives an overview of the state-of-the-art of key biomass conversion technologies currently deployed and technologies that may play a key role in the future, including possible linkage to $\mathrm{CO}_{2}$ capture and sequestration technology (CCS). In doing so, special attention will be paid to production of biofuels for the transport sector, because this is likely to become the key emerging market for large-scale sustainable biomass use.

\section{Technology Overview}

Conversion routes for producing energy carriers from biomass are plentiful. Figure 1 illustrates the main conversion routes that are used or under development for production of heat, power and transport fuels. First, conversion technologies for production of power and heat will be summarized (combustion, gasification and digestion in Section 2.1), followed by the technologies available or developed to produce transportation fuels (fermentation, gasification and extraction in Section 2.2), in each case distinguishing between current and prospective availability.

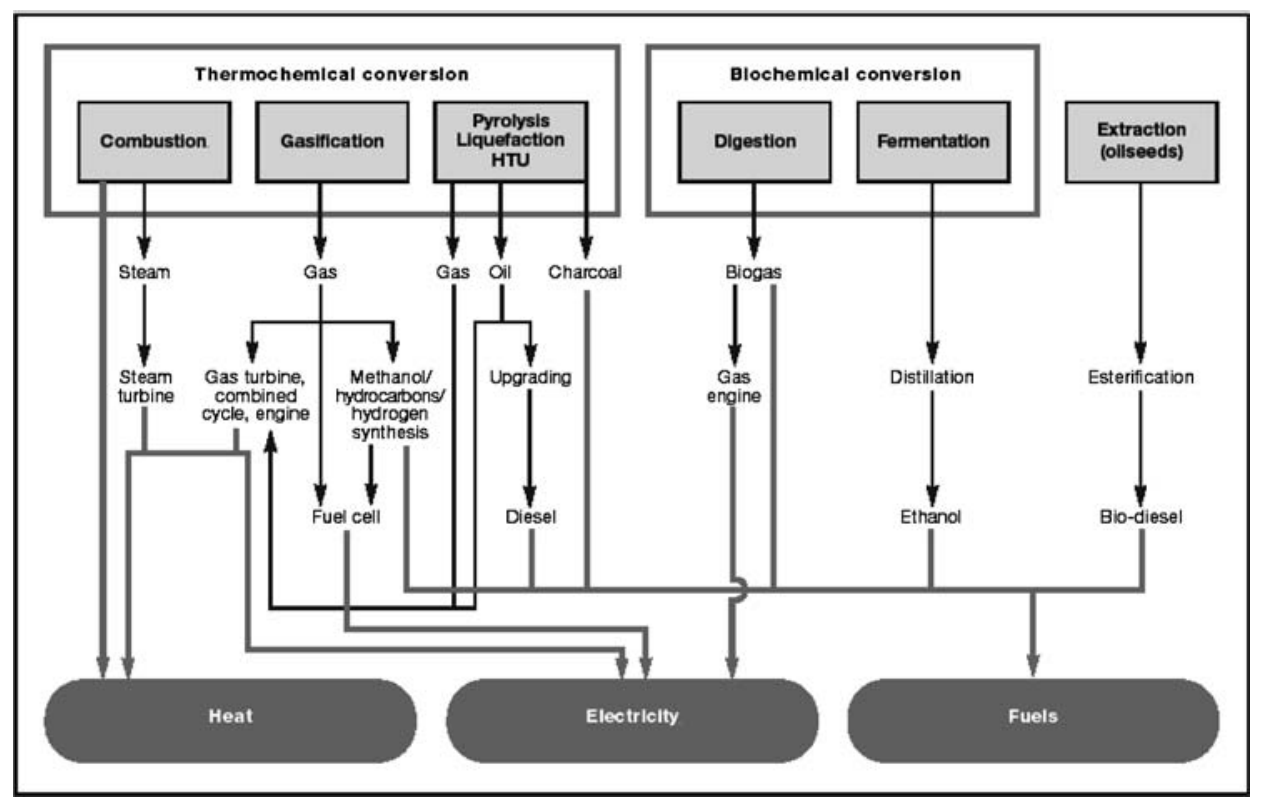

Figure 1. Main conversion options for biomass to secondary energy carriers (Turkenburg 2000). Some categories represent a wide range of technological concepts as well as capacity ranges at which they are deployed, which are dealt with further in the main text. 


\subsection{COMBUSTION, GASIFICATION, PYROLYSIS AND DIGESTION FOR POWER \& HEAT}

Production of heat (domestic, industrial), and electricity or combined heat and power (CHP) is possible through a portfolio of options (see Figure 1). Below, the most important technologies, which are or have been deployed so far with respect to their role, status and generic performance levels are discussed. Also some of the key options under development and that could play an important role in the coming decades are included. Some emphasis is on the European context, since development and deployment of a wide array of modern bio-energy technologies has been pursued in this world region. Technologies relevant to low income developing countries are not reviewed in detail.

Table I summarizes key performance figures with respect to costs, efficiency and resulting costs ranges of power and heat produced for given assumptions, as well as some summarizing remarks on the status of each technology discussed.

\subsubsection{Combustion}

- Domestic heating: A classic application of biomass combustion is heat production for domestic applications. This is still a major market for biomass for domestic heating in countries like Austria, France, Germany and Sweden. Use of wood in open fireplaces and small furnaces in houses is generally poorly documented, but estimated contributions to meet heat demand are considerable in countries mentioned. Traditional use of wood generally has a low efficiency (sometimes as low as 10\%) and generally goes with considerable emissions e.g. of dust and soot. Technology development has led to the application of strongly improved heating systems, which are for example automated, have catalytic gas cleaning and make use of standardized fuel (such as pellets). The efficiency benefit compared to open fireplaces is considerable: open fireplaces may even have a negative efficiency over the year (due to heat losses through the chimney), while advanced domestic heaters can obtain efficiencies of 70-90\% with strongly reduced emissions. The application of such systems is widespread in Scandinavia, Austria and Germany. In Sweden in particular, a significant market has developed for biomass pellets, which are fired in automated firing systems. (van Loo and Koppejan 2002)

- District heating and CHP: The application of biomass fired district heating is widely applied in Scandinavian countries and Austria. In Scandinavia, biomass fired CHP really took off in the eighties as a result of national climate and energy policies. In the first stages, retrofits of existing coal-fired boilers were popular. Over time, the scale of CHP systems shows an increasing trend, with apparent advantages from higher electrical efficiencies and lower costs. This was also combined with a developing biomass market, allowing for more competitive and longer distance supplies of biomass resources (especially forest residues) (Hillring 2002). During the nineties, Denmark deployed a major programme for 


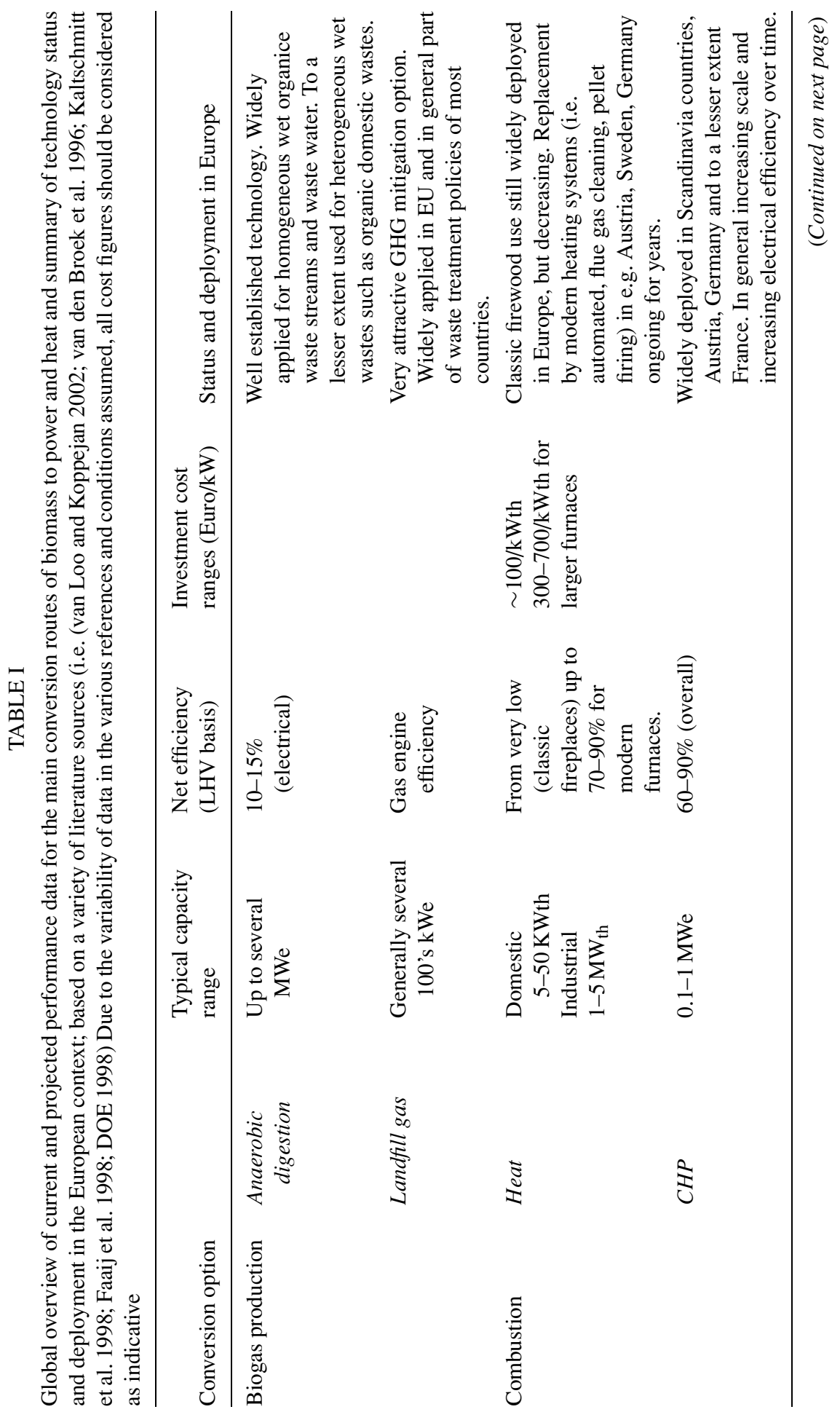




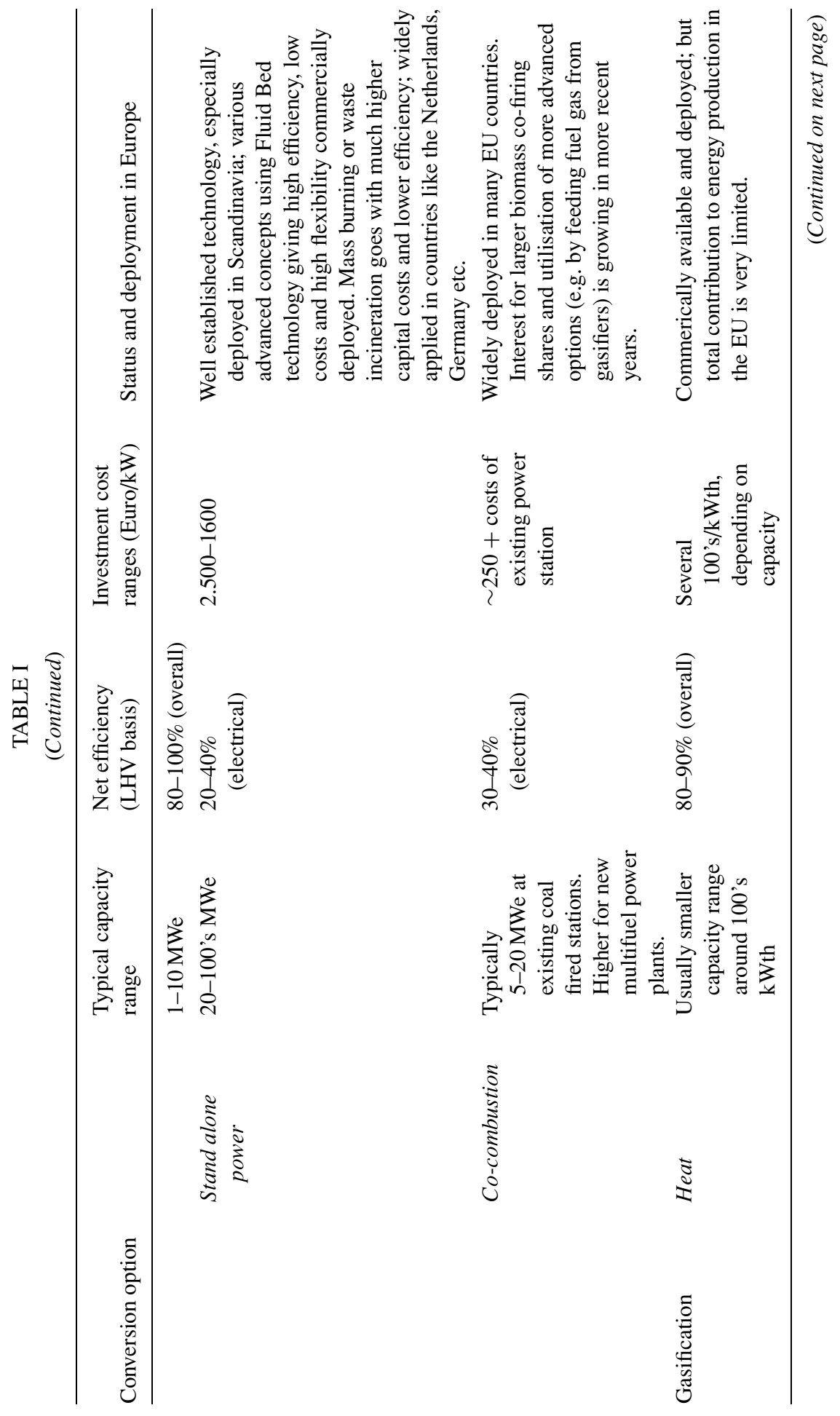




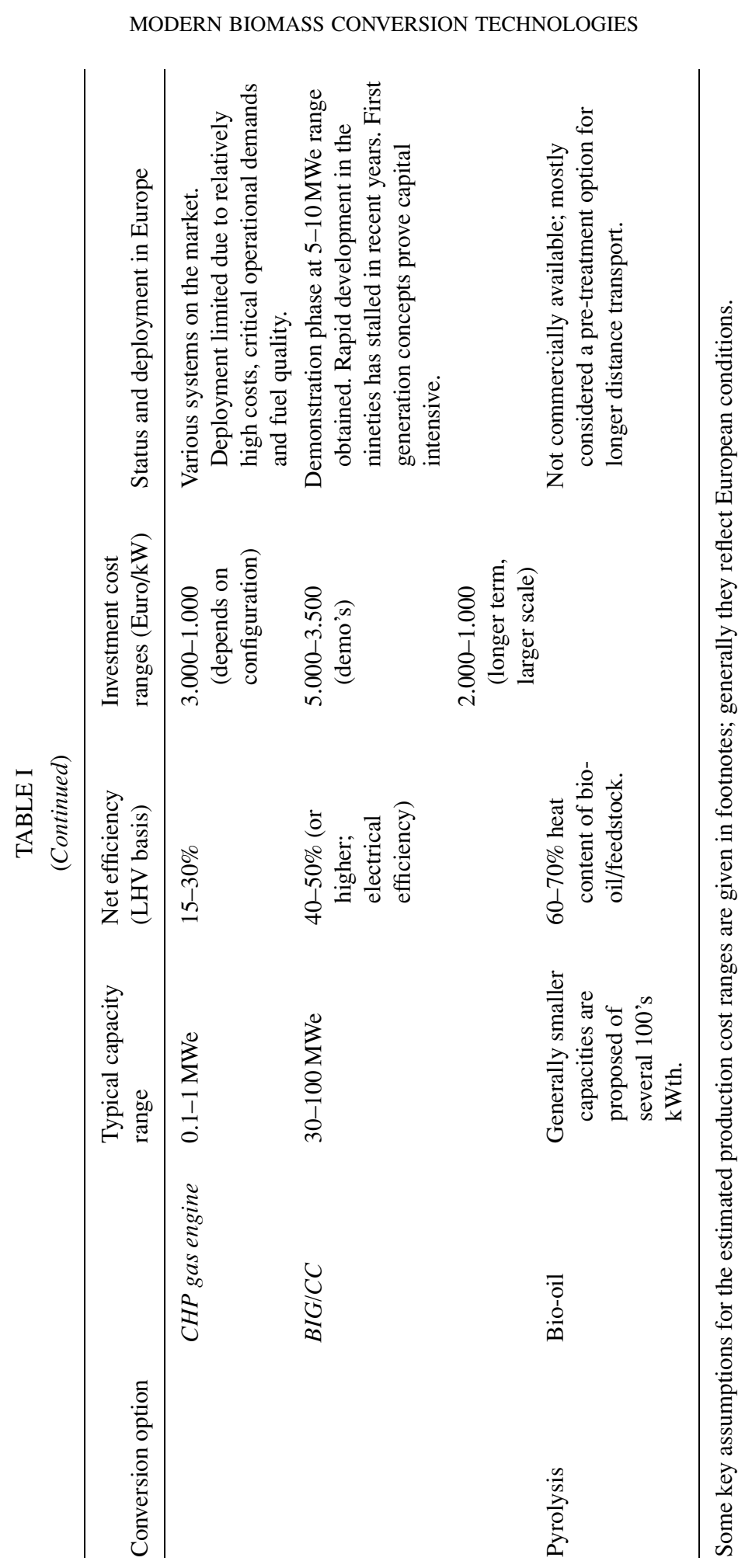


utilising straw. Various technical concepts were developed and deployed such as the so-called cigar burners combined with efficient straw baling equipment, transport and storage chains. Other innovations were needed to deal with the difficult combustion characteristics of straw such the high alkali and chlorine content. This lead to complex boiler concepts, e.g. involving two-stage combustion, but also new pre-treatment techniques such as straw washing (Nikolaisen et al. 1999). Austria, another leading country in deploying biomass fired CHP focused on smaller scale systems on village level, generally combined with local fuel supply systems. All these countries have colder climates making CHP economically attractive. Furthermore, involvement of local communities has proven important. Municipalities and forest owners are often the owners of the CHP-plants. Energy costs of those systems are usually somewhat higher. Local societal support is generally strong though, especially due to the employment and expenditures that benefit the local community. However, high labour costs also led to high degrees of automation, with unmanned operation typical for many of the newer facilities (Serup et al. 1999).

- Larger-scale combustion of biomass for the production of electricity (plus heat and process steam) is applied commercially word wide. Many plant configurations have been developed and deployed over time. Basic combustion concepts include pile burning, various types of grate firing (stationary, moving, vibrating), suspension firing and fluidized bed concepts. Key sector for the application for biomass combustion for power generation is the paper- and pulp (P\&P) industry for combustion of black liquor and waste incineration. Conventional boilers for combined production of power and process steams and recovery of pulping chemicals is common technology for the $\mathrm{P} \& \mathrm{P}$ sector. Waste incinerators were widely deployed starting in the eighties in countries like Germany and the Netherlands, combined with very stringent emission standards. Typically such plants have large capacities (i.e. around 1 Mtonne capacity per plant per year) moving grate boilers (which allow mass burning of very diverse waste properties), low steam pressures and temperatures (to avoid corrosion) and extensive flue gas cleaning. Typical electrical efficiencies are between 15 to over $20 \%$ and more efficient designs (reaching some 30\% electrical efficiency) are now commissioned. Mass burning became the key waste-to-energy technology deployed in Europe, but is also relatively expensive with treatment costs in the range of 50-150 Euro/tonne (off-set by tipping fees) (Faaij et al. 1998). Typical capacities for stand-alone biomass combustion plants (typically using wood such as forest residues, as fuel) range between 20-50 MWe, with related electrical efficiencies in the $25-30 \%$ range. Such plants are only economically viable when fuels are available at low costs or when a carbon tax or a feed-in tariff for renewable electricity is in place. In recent years advanced combustion concepts have penetrated the market (Faaij 2004). The application of fluid bed technology and advanced gas cleaning allows for efficient and production of electricity (and heat) from biomass. On a scale of about 50-80 MWe, electrical 
efficiencies of 30-40\% are possible (van Loo and Koppejan 2002; DOE 1998; van den Broek, et al. 1996). Finland is on cutting edge of the field with development and deployment of Bubbling Fluidized Bed (BFB) and Circulating Fluidized Bed (CFB) boilers with high fuel flexibility, lower specific investment costs, high efficiency and deployed on a large scale. One of the latest plants realized in Finland has a capacity of $500 \mathrm{MW}_{\text {th }}$ and is co-fired with a portfolio of biomass fuels, partly supplied by water transport.

- Co-combustion: Co-combustion of biomass, in particular in coal-fired power plants is the single largest growing conversion route for biomass in many EU countries (e.g. in Spain, Germany, and the Netherlands to name a few). The advantages of co-firing are apparent: the overall electrical efficiency is high (usually around $40 \%$ ) due to the economies of scale of the existing plant and investments costs are low to negligible when high quality fuels as pellets are used. Also, directly avoided emissions are high due to direct replacement of coal. Combined with the fact that many coal-fired power plants in operation are fully depreciated, this makes co-firing usually a very attractive GHG mitigation option. In addition, biomass firing leads to lowering sulphur and other emissions (see e.g. (Meuleman and Faaij 1999)). For some countries though, biomass firing is also a route to avoid the need for investing in additional flue gas cleaning equipment otherwise needed for $100 \%$ coal firing. Generally, relatively low co-firing shares are deployed with very limited consequences for boiler performance and maintenance. Because many plants are now equipped with some co-firing capacity interest for higher co-firing shares (e.g. up to 40\%) is rising. Technical consequences e.g. for feeding lines and boiler performance are more severe though, and current development efforts focus on those issues (van Loo and Koppejan 2002). Power plants capable of firing natural gas or coal with various biomass streams are built in Denmark (e.g the Avedore plant) with the benefit of gaining economies of scale as well as reduced fuel supply risks. In Denmark straw is a common fuel. The chlorine and alkaline rich straw caused problems in conventional combustion systems through increased corrosion and slagging. In multi-fuel systems however, straw can be used for raising low temperature steam, after which the steam is superheated by fossil fuels. This approach more ot less eliminates these problems (Nikolaisen et al. 1999).

\subsubsection{Gasification}

Gasification as a means to convert a diversity of solid fuels to combustible gas or syngas received considerable attention in the eighties worldwide and also in Europe. Gasification converts biomass into fuel gas, which can be further converted or cleaned prior to combustion (e.g. in a gas turbine; when integrated with a combined cycle this leads to a BIG/CC Biomass Integrated Gasification/Combined Cycle plant).

The use of gasification for production of fuels will be discussed further in Section 2.2. In this section we will first focus on production of heat and power deploying 
biomass gasification. We will distinguish between smaller scale gasification (i.e. in the 10 's of $\mathrm{kW}$ th to around $1 \mathrm{MW}_{\text {th }}$ capacity range and generally involving fixed bed gasification concepts) and larger scale gasification, generally linked to Fluid Bed concepts.

- Smaller scale gasification: at the end 80's and beginning of the90's, small-scale gasification received major support. Downdraft or updraft, fixed bed gasifiers with capacities of less than a $100 \mathrm{~kW}$ th up to a few $\mathrm{MW}_{\text {th }}$ were developed and tested for small-scale power and heat generation using diesel or gas engines. Heat production using small gasifiers is commercially established. Finland in particular was succesfull in the 80's in deploying smaller scale (Bioneer) gasifiers for heat production. Nevertheless, gasification for production of heat finds a strong competitor in combustion. A key concept pursued for a long period of time was the use of agricultural residues close to its source, thus minimizing transport distances. A wide array of concepts for gasifiers, gas cleaning and system integration for such concepts was proposed and tested in a wide variety of conditions. Technology was also exported to many developing countries with support from international bodies such as the World Bank. The key drivers here were rural development and electrification. So far, despite major efforts, investments and large number of demonstration units, the concept of small-scale gasification linked to gas or diesel engines has never taken off. Small (fixed bed) gasifiers coupled to diesel/gas engines (typically for 100$200 \mathrm{kWe}$ systems with an approximate, modest, electrical efficiency of 15$25 \%$ ) are commercially available on the market. Especially in India, succesful implementation has been achieved. However, the critical demands of smallscale gasifiers as regards fuel quality (preferably standardized and hence more expensive fuel such as pellets) and careful operation along with high costs, especially for effective gas cleaning given the severe emission standards, have so far hampered their wide deployment in the EU (Kaltschmitt et al. 1998; Stassen 1995). Possibly, in the longer term, standardized gasification systems ('pre-packaged') using fuel cells and micro-turbines could mean a breakthrough for small scale electricity production from biomass, but such systems need further development and will depend on cheap and reliable fuel cells and again, major advances in small scale gas cleaning.

- Larger scale (CFB) biomass gasification: Larger gasifiers (i.e. over several 10's $\mathrm{MW}_{\text {th }}$ capacity are generally associated with Circulating Fluidized Bed concepts which have high fuel flexibility. At atmospheric pressure (ACFB) gasifiers are used for production of (raw) producer gas and process heat (e.g. in Italy, Austria, Sweden and Germany) but not in very large numbers. Biomass Integrated Gasification/Combined Cycle (BIG/CC) systems combine flexibility with respect to fuel characteristics with a high electrical efficiency. Electrical efficiencies around $40 \%$ (LHV basis) are possible on a scale of about $30 \mathrm{MWe}$ on shorter term (Consonni and Larson 1996; Faaij et al. 1997). BIG/CC became the centre of attention in EU and various national programs in the first 
half of the nineties. The promise of this technology, allowing for high electrical efficiency at modest scales combined with modest capital costs, resulted in a variety of research and demonstration initiatives. Furthermore, BIG/CC concepts can achieved low emission to air levels, because the fuel gas needs severe cleaning prior to combustion to meet gas turbine specifications (Faaij et al. 1997). Demonstration projects were launched in various countries and for various gasification concepts: in Brazil a GEF/World Bank supported project was set up to demonstrate a $30 \mathrm{MWe}$ ACFB BIG/CC unit fired with cultivated Eucalyptus (Elliott 1993). In the same period in Sweden, the first BIG/CC unit (the BIOFLOW pilot-project), based on a pressurized gasification process (PCFB) has gained several thousands of hours of operational experience. An atmospheric (ACFB) BIG/CC system was commissioned in 2000 in Yorkshire, UK but bio-fuel operations stopped after a testing period though the plant has since run on natural gas. An important project in the US is the demonstration of the indirect FERCO gasification concept at the existing Burlington power station. In addition, a variety of national initiatives were launched aimed at pre-commercial or demonstration units of BIG/CC technology (in particular in the EU) (Morris et al. 2005). However, in practice the realization of the demonstration projects proved to be difficult. Costs of first generation units proved to be very high. The first generation of BIG/CC systems shows high unit capital costs. Depending on the scale, price levels of 5,000-3,500 Euro/kWe are quoted (Faaij et al. 1998), which is still far from the desired 1,500-2,000 Euro/kWe, which could bring BIG/CC in a competitive area. Various technological issues (e.g. concerning pre-treatment and tar removal) still need to be resolved. Later in the nineties, many utilities faced rapid market liberalization in the energy sector and expensive demonstration activities proved to be hard to pursue. Various demonstration units (such as ARBRE and BIOFLOW) were put out of operation recently. Co-firing and proven combustion technology (which also develops over time) is generally favoured by the risk-averse energy sector. This has led to the deplorable situation of stalled development of a technology that, on a somewhat longer term, is capable of producing power from biomass at competitive price levels. At somewhat larger scale (over $100 \mathrm{MWe}$ ) and considering the ongoing improvement of gas turbine technology, the cost reduction potential of BIG/CC systems is considerable, as has been evaluated by numerous studies (Williams and Larson 1996; Faaij et al. 1998; Solantausta et al. 1996). The combination of high electrical efficiencies with relatively low unit capital costs can make the use of cultivated biomass as feedstock economically feasible for many areas in the world. So far, however, development is slow.

- Gasification for co-firing: Gasification is also a route towards large co-firing shares of existing (coal-fired) power plants, avoiding the need for additional solid fuel feeding lines and allowing for better control of the combustion process. Successful deployment of (A)CFB gasifiers is recently shown in co-firing schemes (e.g. Lahti in Finland and Amer in the Netherlands) (van Loo and 
Koppejan 2002). An interesting alternative application for producer gas from biomass gasification is to use it for co-firing in existing (or new) natural gas fired combined cycles. In this way, economies of scale are utilised resulting at in low cost and (very) high overall efficiencies (currently up to $60 \%$ for NG fired combined cycles), combined with a secure fuel supply since one can vary the share of fuel gas and natural gas fired, (Rodrigues et al. 2003). So far, this option has not been demonstrated anywhere in the world, but research efforts are increasing and it could prove to be of major importance on short term given that co-firing opportunities at existing coal-fired power plants are increasingly utilised already.

\subsubsection{Production of Bio-Oils: Pyrolysis and Liquefaction Processes}

Pyrolysis converts biomass at temperatures around $500^{\circ} \mathrm{C}$ in absence of oxygen to liquid (bio-oil), gaseous and solid (char) fractions. With flash pyrolysis techniques (fast pyrolysis) the liquid fraction can be maximized (up to $70 \%$ of the thermal biomass input). Bio-oil contains about 40 weight percent of oxygen and is corrosive and acidic. Crude bio-oil can in principle (after some modifications and only for better quality oils) be used for firing engines and turbines. The oil can also be upgraded (e.g. via hydrogenation) in order to reduce the oxygen content. But upgrading comes with both economic and energy penalties. Pyrolysis and upgrading technology is largely in the demonstration phase (Bridgewater 1998). Liquefaction (conversion under high pressure) and HTU, or Hydro Thermal Upgrading (a process originally developed by Shell and in pre-pilot phase, that converts biomass at a high pressure in water and moderate temperatures to bio-crude (Naber et al. 1997)) are other ways of producing 'raw intermediate' liquids from biomass.

Up to now, pyrolysis is less well developed than gasification (and liquefaction options even more so). Major attention since end eighties/beginning nineties was especially caused by the potential deployment of this technology on small scale in rural areas and as feedstock for the chemical industry. Reducing transport costs because of the higher energy density of bio-oil compared to untreated biomass was used as another key argument.

Although considerable experience was gained over time, still, few successful demonstration units were realized, (prime examples shown by Fortum, a Finnish Oil company and Dynamotive in Canada leading commercialization of pyrolysis technology). Actual market implementation is so far in its infancy. Pyrolysis now receives increasing attention as a pre-treatment step for long distance transport of bio-oil that can be used in further conversion (e.g. efficient power generation or (entrained flow) gasification for syngas production).

\subsubsection{Digestion}

- Biogas: Anaerobic digestion of biomass has been demonstrated and applied commercially with success in a multitude of situations and for a variety of feedstocks such as organic domestic waste, organic industrial wastes, manure, 
sludges, etc. . Digestion is particularly suited for wet biomass materials, but it has a low overall electrical efficiency when the gas produced is used to fuel gas engine driven generators (typically some 10-15\%). Biomass to gas conversion can reach some 35\% strongly depending on the feedstock. Digestion has been deployed for a long time in the food and beverage industry to process waste water with high loads of organic matter. Currently, advanced, large scale, systems for wet industrial waste streams are applied in many countries and codigestion of for example manure and wet organic process residues is particularly succesfull at present. Countries like Denmark and the Germany have a strong position with advanced digestion systems used for processing various wet waste streams (Braber 1995).

- Landfill gas utilisation: A specific source of biogas is landfills. The production of methane rich landfill gas from landfill sites makes a significant contribution to atmospheric methane emissions. In many situations the collection of landfill gas and production of electricity by converting this gas in gas engines is profitable and the application of such systems has become widespread. The benefits are obvious: useful energy carriers are produced from gas that would otherwise contribute to a build-up of methane GHG in the atmosphere, which has stronger GHG impact than the $\mathrm{CO}_{2}$ emitted from the power plant (Faaij et al. 1998). This makes landfill gas utilisation in general a very attractive GHG mitigation option, widely adopted throughout the EU and North America and increasingly deployed in other world regions.

\subsection{PRODUCTION OF TRANSPORTATION FUELS VIA GASIFICATION, FERMENTATION AND EXTRACTION}

As follows from Figure 1, three main routes can be distinguished to produce transportation fuels from biomass: gasification can be used to produce syngas that can be converted to methanol, Fischer-Tropsch liquids, DiMethylEther (DME) and hydrogen. Production of ethanol can take place via direct fermentation of sugar and starch rich biomass, the most utilized route for production of biofuels to date, or this can be preceded by hydrolysis processes to convert ligno-cellulosic biomass to sugars first. Finally, biofuels can be produced via extraction from oil seeds (vegetal oil from e.g. rapeseed or palmoil), which can be esterified to produce biodiesel.

The characteristics of those fuels differ widely (see Table II): hydrogen, being a very light gas, requires very extensive infrastructure. All other fuels considered, except DME, are liquids and can be stored and distributed with relatively conventional infrastructure. Ethanol and especially methanol have a lower energy density than gasoline, so for the same amount of energy in a vehicle more weight has to be taken on board. Other aspects concern the toxicity and environmental impacts of the fuels due to leakages or calamities. Gasoline and diesel partly contain aromates, with carcinogenic properties. 
TABLE II

Some main properties of biofuels for the transport sector

\begin{tabular}{|c|c|c|c|}
\hline Fuel & $\begin{array}{l}\text { Density }(\mathrm{kg} / \mathrm{litre}) \\
\left(\text { at } 15^{\circ} \mathrm{C}\right)\end{array}$ & $\begin{array}{l}\text { Energy density } \\
(\mathrm{MJ} / \mathrm{kg})(\mathrm{HHV})\end{array}$ & Other aspects \\
\hline Hydrogen & 0.07 & 142 & $\begin{array}{l}\text { Lighter than air, } \\
\text { low explosion limits }\end{array}$ \\
\hline Methanol & 0.8 & 23 & $\begin{array}{l}\text { Toxic in direct contact } \\
\text { octane number } 88.6 \text { (gasoline } 85 \text { ) }\end{array}$ \\
\hline DME & 0.66 & 28.2 & $\begin{array}{l}\text { Vapour pressure } 5.1 \mathrm{bar} \\
\text { at } 20^{\circ} \mathrm{C} \text {. }\end{array}$ \\
\hline $\begin{array}{l}\text { Fischer-Tropsch } \\
\text { gasoline }\end{array}$ & 0.75 & $46-48$ & $\begin{array}{l}\text { Very comparable to } \\
\text { diesel and gasoline; } \\
\text { zero sulpur, no aromates }\end{array}$ \\
\hline Ethanol & 0.79 & 30 & $\begin{array}{l}\text { Octane number } 89.7 \\
\quad \text { (gasoline } 85 \text { ) }\end{array}$ \\
\hline $\begin{array}{l}\text { Diesel from bio-oil/ } \\
\text { bio-crude }\end{array}$ & 0.85 & 47 & $\begin{array}{l}\text { When fully } \\
\text { de-oxygenated }\end{array}$ \\
\hline Bio-diesel & 0.88 & 42 & $\begin{array}{l}\text { Cetane number: } 58 \\
\quad(\text { diesel } 47.5)\end{array}$ \\
\hline Gasoline & 0.75 & 46 & $\begin{array}{l}\text { Depending on refining process, } \\
\text { contains sulphur and aromates }\end{array}$ \\
\hline Diesel & 0.85 & 46 & $\begin{array}{l}\text { Depending on refining process, } \\
\text { contains sulphur and aromates }\end{array}$ \\
\hline
\end{tabular}

Methanol is not carcinogenic but is a more dangerous liquid than gasoline when it comes into contact with human skin. Measures need to be taken to reduce exposure risks compared to gasoline and diesel, such as closed filling systems (e.g. as applied for LPG). This will result in (somewhat) higher (investment) costs. Fischer-Tropsch liquids and ethanol are barely toxic and the sulphur and aromate content of those fuels are zero, which are advantages compared to gasoline and diesel. In addition, the existing infrastructure for gasoline and diesel can be used (IEA 2004).

\subsubsection{Methanol, Hydrogen and Hydrocarbons via Gasification}

Methanol, hydrogen and Fischer-Tropsch diesel can be produced from biomass via gasification. All routes need very clean syngas before the secondary energy carrier is produced via relatively conventional gas processing methods. Besides $\mathrm{MeOH}$, hydrogen and FT-liquids, DME (DiMethylEther) and SNG (Synthetic Natural Gas) can also be produced from syngas. We will however focus on the first three fuels mentioned.

Several routes involving conventional, commercial, or advanced technologies under development, are possible. Figure 2 pictures a generic conversion flowsheet for this category of processes. A train of processes to convert biomass to required gas specifications precedes the methanol or FT reactor, or hydrogen separation. The 


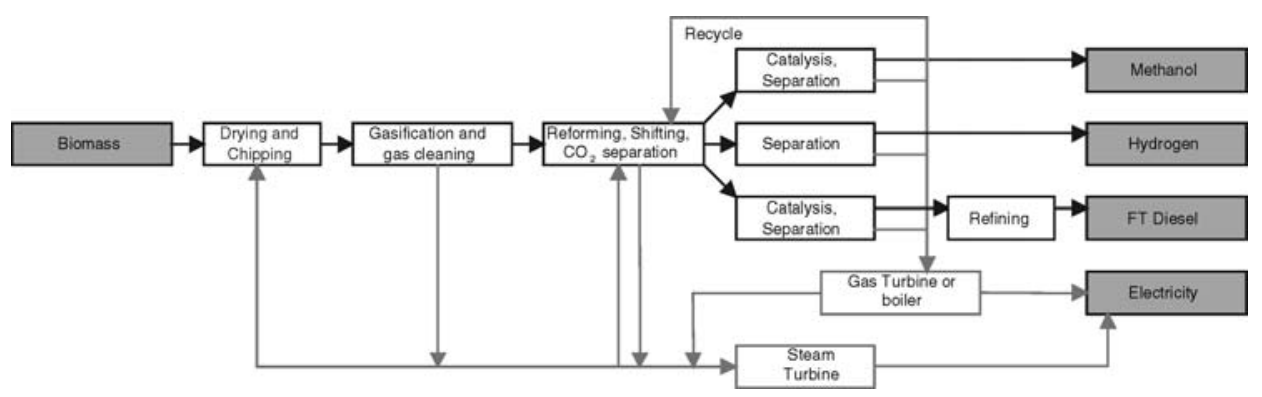

Figure 2. Generic flowsheet for methanol, hydrogen, or FT diesel production, via gasification of biomass.

gasifier produces syngas, a mixture of $\mathrm{CO}$ and $\mathrm{H}_{2}$, and a few other compounds. The syngas then undergoes a series of chemical reactions. The equipment downstream of the gasifier for conversion to $\mathrm{H}_{2}$, methanol or FT diesel is the same as that used to make these products from natural gas, except for the gas cleaning train. A gas turbine or boiler, and a steam turbine optionally employ the unconverted gas fractions for electricity co-production (Hamelinck 2004).

So far, commercial biofuels production via gasification does not take place, but interest is on the rise and development efforts have been made over the past decades. Partly as a result of the oil crises, an interest in biomass derived syngas for the production of transport fuels (such as methanol) was pursued during the 1980 's. Pressurized gasification for methanol production from biomass was tested and developed in France and Sweden. Kemira (a Finnish company active in the production of fertilizers) installed a large-scale CFB gasifier in Oulu, (Finland) for producing syngas for an ammonia factory (which was shut down). Also noteworthy is the installed gasification capacity (entrained flow) at Schwarze Pumpe (former East Germany) for producing methanol from waste streams, which is a major industrial experience with this technology. Low energy prices worsened the position of advanced gasification technologies for large-scale applications. Kaltschmitt et al. (1998) renewed attention for using gasification technology for production of transport fuels, in particular Fischer-Tropsch diesel and hydrogen. In Freiburg - Germany, the company Choren demonstrates FT-diesel production via biomass gasification. Although this seems a viable development given the techno-economic potential of such concepts (see also Table III), the technological challenges remain and are likely to be more complex than for BIG/CC concepts because gas cleaning needs to be more severe in order to protect downstream catalytic gas processing equipment.

Once clean syngas is available, known process technology for producing methanol, FT-liquids, DME and hydrogen can be applied. The main development challenges are gas cleaning, scale-up of processes and process integration. More recent technological concepts, such as liquid phase methanol production and once- 


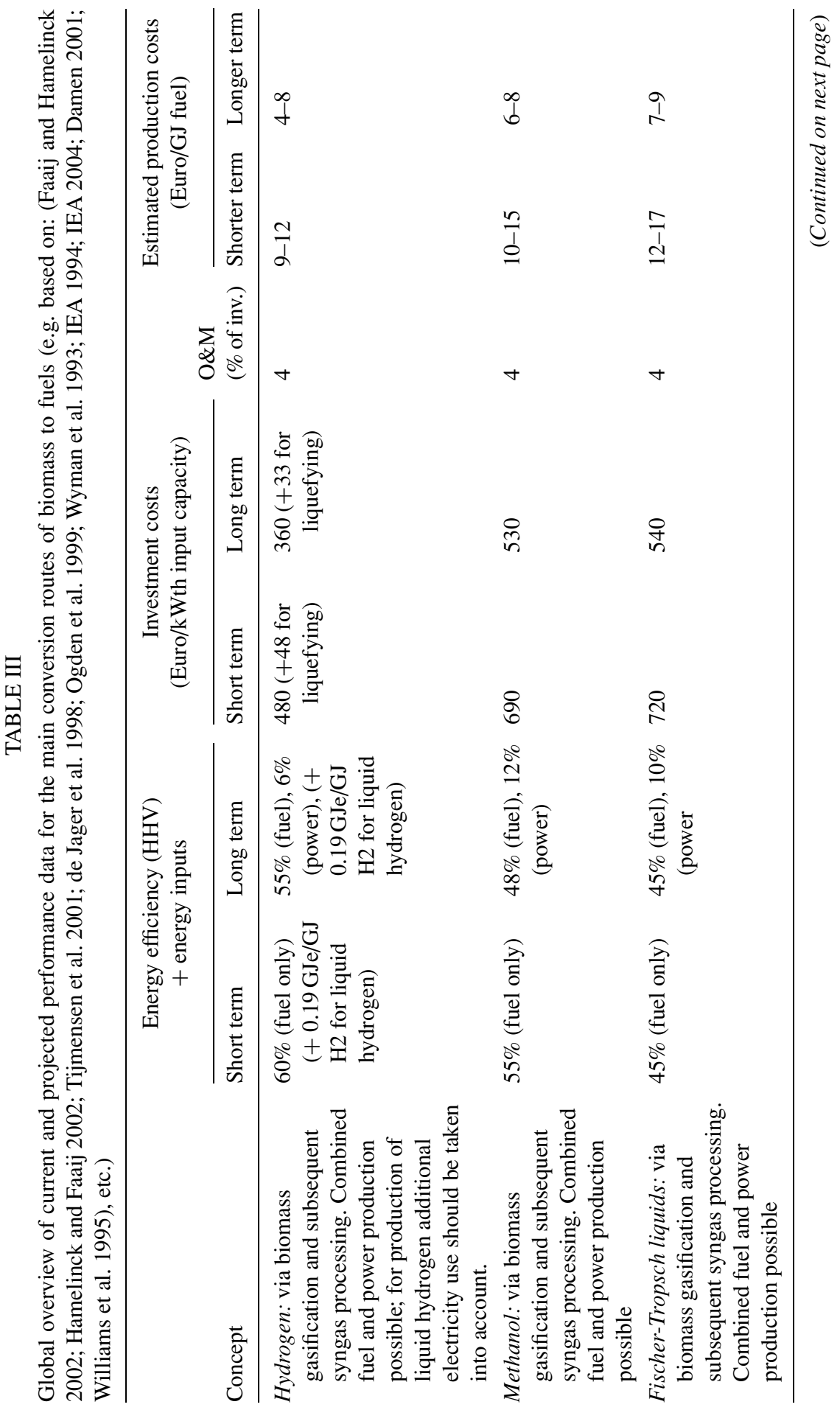




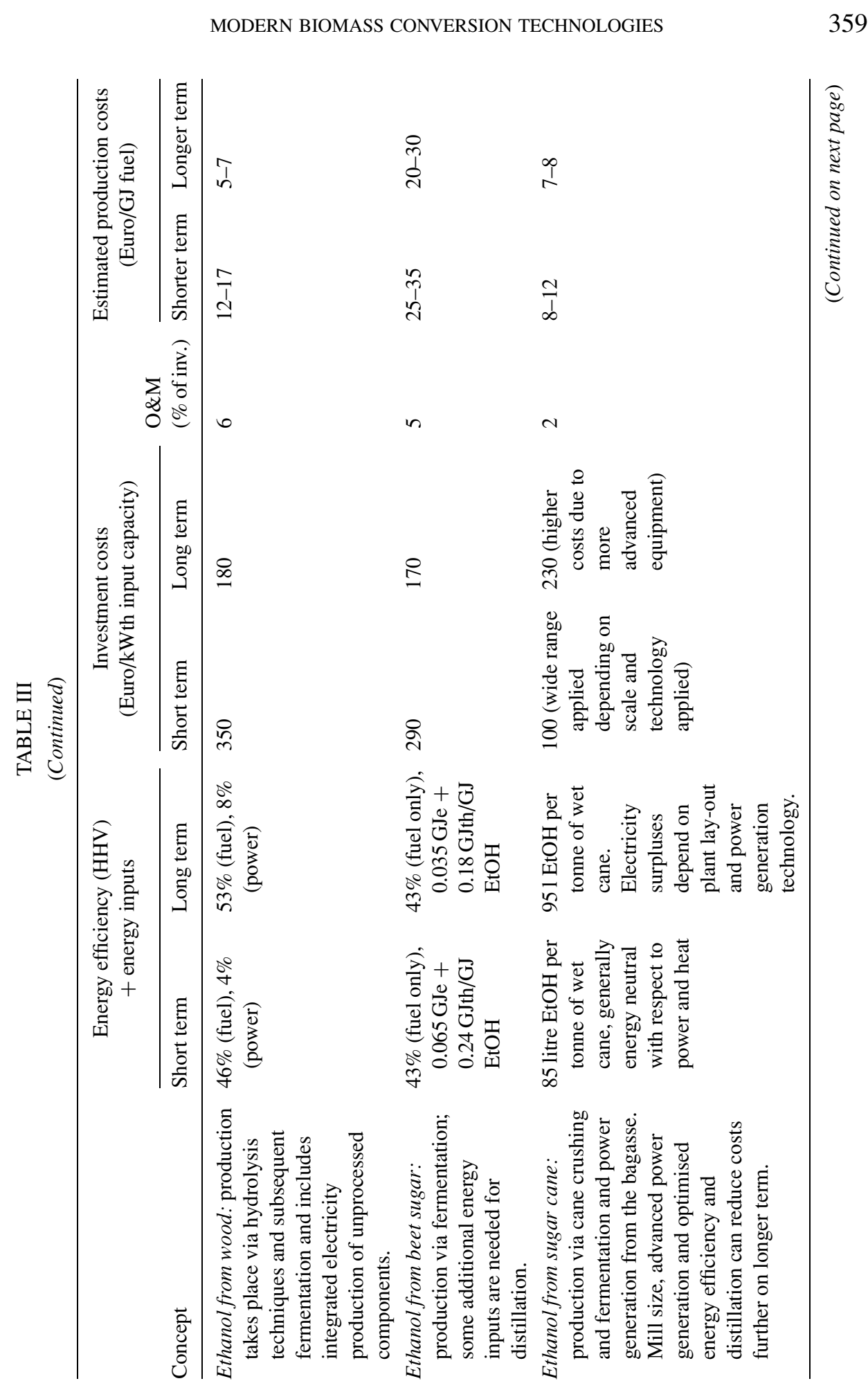


360

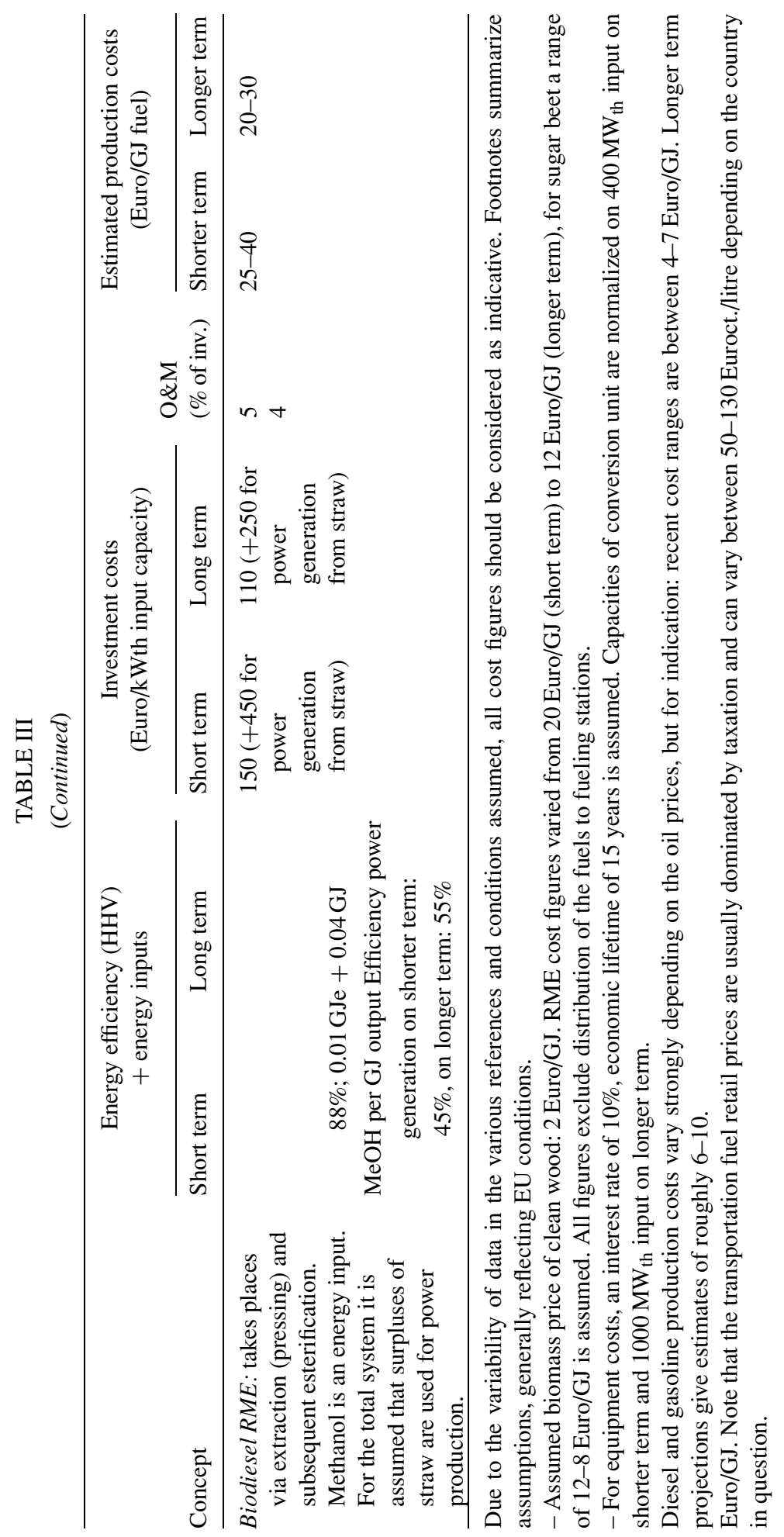


through Fischer-Tropsch synthesis (combined with electricity generation) and new gas cleaning and separation technology offer potentially lower production costs and higher overall efficiencies on the longer term.

More research, demonstration and development activities over a prolonged period of time are however needed to reach such a situation. In countries like Germany, the Netherlands and Sweden interest to develop advanced gasification for syngas production is on the rise again and plays an important role in long-term RD\&D strategies.

Overall energetic efficiencies of relatively 'conventional' production facilities, could be close to $60 \%$ (on a scale of about $400 \mathrm{MW}_{\text {th }}$ input). Deployment on large scale (e.g over $1000 \mathrm{MW}_{\text {th }}$ ) is required to benefit maximally from economies of scale, which are inherent to this type of installations. In total however, this (set of) option(s) has a strong position from both efficiency and economic perspective (Tijmensen et al. 2002; Hamelinck and Faaij 2002; Williams et al. 1995; Hamelinck et al. 2004). Generic performance ranges resulting from detailed pre-engineering studies are reported in Table III.

Application of $\mathrm{CO}_{2}$ capture. Figure 2 shows that after gasification, $\mathrm{CO}_{2}$ removal is or can be deployed. For hydrogen production this is evident, because all carbon monoxide produced is shifted to hydrogen and $\mathrm{CO}_{2}$. Optimal performance of Fischer-Tropsch synthesis requires removal of $\mathrm{CO}_{2}$ to obtain higher partial pressures of the reactants (Tijmensen et al. 2002).

(Mollersten et al. 2003), have indicated that a substantial amount of carbon in the original biomass can be captured as $\mathrm{CO}_{2}$ at relatively low additional costs, because $\mathrm{CO}_{2}$ concentrations are generally much higher than in typical fuel gas from combustion processes. Combining the use of sustainably grown biomass with (partial) $\mathrm{CO}_{2}$ capture allows for overall negative $\mathrm{CO}_{2}$ emissions per unit of energy produced on a life cycle basis.

It is beyond the scope of this paper to address all opportunities to combine fossil fuels with biomass in flexible conversion facilities producing fuels and other outputs, but clearly, gasification based conversion platforms could offer flexible fuel production from biomass and coal as well as natural gas.

Organizing large-scale biomass supplies may be difficult on short term, making a co-feeding strategy, e.g. with coal, attractive on short term. When equipped with $\mathrm{CO} 2$ capture facilities, the input share of fossil fuel can still become "carbon neutral" (see e.g. (Celik et al. 2004), who have analysed that about 50\% of the carbon in gasified coal can be captured when producing FT-liquids via gasification). When more biomass would be utilized, negative emissions could be obtained. Also, existing large-scale gasification technology (entrained flow) can be used, because such gasification processes are developed and deployed for coal and heavy oil residues. Biomass feedstock could be supplied as crude bio-oils obtained via pyrolysis in the biomass production areas or treated via torrefaction, which basically means 'roasting' of the biomass reducing the moisture content and facilitating grinding 
and further pelletisation. Such densification steps reduce long distance transport costs and facilitate feeding to pressurized gasification systems. Some exploratory work on large scale and long distance biomass supplies for large-scale syngas production has been done (see e.g. Hamelinck et al. 2004 and Calis et al. 2003) with promising results, indicating that this is a concept that deserves further study and development efforts.

\subsubsection{Fermentation; Production of Ethanol}

- Ethanol from sugar and starch: Production of ethanol via fermentation of sugars is a classic conversion route, which is applied for sugar cane, maize and cereals on a large scale, especially in Brazil, the United States and France. Sweden and Spain have more modest production levels of ethanol. Ethanol is generally mixed with gasoline, which, at low percentages, can be done without adaptations to the current vehicle fleet. Ethanol has the advantage that it lowers $\mathrm{NO}_{x}$ and dust emissions to some extent compared to straight gasoline. The US and European programmes are particularly used for converting surpluses of food crops to a useful (by) product. Ethanol production from food crops like maize and cereals is however far from competitive when compared to gasoline and diesel prices and is not likely to achieve major cost reduction on longer term. Ethanol production from sugar cane, however has established a strong position in Brazil and increasingly in other countries in tropical regions (such as India, China and various countries in Sub-Saharan Africa). Production costs of ethanol in Brazil have steadily declined over the past few decades and have reached a point where ethanol is competitive with production costs of gasoline (Rosillo-Calle and Cortez 1998). As a result, bio-ethanol is no longer financially supported in Brazil and competes openly with gasoline (Goldemberg et al. 2004). Large scale production facilities, better use of bagasse and trash residues from sugar cane production e.g. with advanced (gasification based) power generation or hydrolysis techniques (see below) and further improvements in cropping systems, offer further perspectives for sugar cane based ethanol production. The key limitations for sugar cane production are climatic and the required availability of good quality soils. Lignocellulosic feedstock production is more flexible in this respect.

- Ethanol from (ligno)-cellulosic biomass: hydrolysis of cellulosic (e.g. straw) and ligno-cellulosic (woody) biomass can open the way towards low cost and efficient production of ethanol from these abundant types of biomass. The conversion is more difficult than for sugar and starch because from lignocellulosic materials, first sugars need to be produced via hydrolysis. Lignocellulosic biomass requires pretreatment by mechanical and physical actions (e.g. steam) to clean and size the biomass, and destroy its cell structure to make it more accessible to further chemical or biological treatment. Also, the lignin part of the biomass is removed, and the hemicellulose is hydrolysed (saccharified) to monomeric and oligomeric sugars. The cellulose can then be hydrolysed 


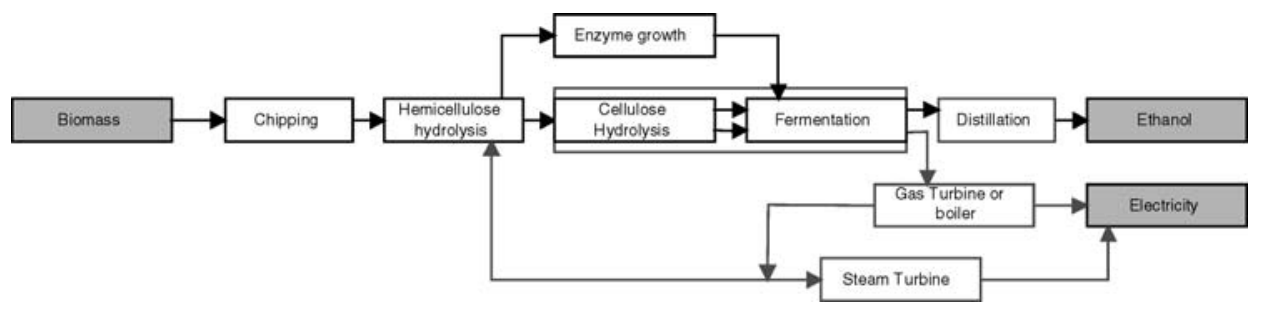

Figure 3. Ethanol production by hydrolysis fermentation schematically.

to glucose. The sugars are fermented to ethanol, which is to be purified and dehydrated. Two pathways are possible towards future processes: a continuing consolidation of hydrolysis-fermentation reactions in fewer reactor vessels and with fewer micro organisms, or an optimisation of separate reactions. As only the cellulose and hemicellulose can be used in the process, the lignin is used for power production (see Figure 3). To date, acid treatment is an available process, which is so far relatively expensive and inefficient. Enzymatic treatment is commercially unproven but various test facilities have been built in North America and Sweden. The development of various hydrolysis techniques has gained major attention over the past 10 years or so, particularly in Sweden and the United States. Because breakthroughs seem to be necessary on a rather fundamental level, it is relatively uncertain how fast attractive performance levels can be achieved (Hamelinck et al. 2004). Assuming, however, that mentioned issues are resolved and ethanol production is combined with efficient electricity production from unconverted wood fractions (lignine in particular), ethanol costs could come close to current gasoline prices (Lynd 1996): as low as 12 Euroct/litre assuming biomass costs of about 2 Euro/GJ. Overall system efficiencies (fuel + power and heat output) could go up to about $70 \%$ (LHV). For the agricultural sector and agro-food industry this technology is interesting already to boost the competitiveness of existing production facilities (e.g. by converting available crop and process residues), which provides drivers for both industry and agriculture to support this technology.

Application of $\mathrm{CO}_{2}$ capture. The fermentation step (see Figure 3) is a process where pure $\mathrm{CO}_{2}$ is produced and capture could be deployed relatively easily. Considering sugar and starch rich biomass sources, about half the biomass is converted to ethanol and the other half into $\mathrm{CO}_{2}$ during the process. $\mathrm{CO}_{2}$ is basically the sole gas released during this step and capture costs are relatively low (largely consisting of compression). When a lignine fraction is present (for woody biomass) a part of the carbon will end up as flue gas after combustion or gasification for production of power and (process) steam. The latter option would allow for $\mathrm{CO}_{2}$ capture before the fuel gas is burned in a gas turbine, which is somewhat more expensive than removal and compression of pure $\mathrm{CO}_{2}$, but it is possible to capture most of the 
carbon not present in the final product. The work of Möllersten cs. provides an overview of combining the use of sustainably grown biomass with (partial) $\mathrm{CO}_{2}$ capture allowing for overall negative $\mathrm{CO}_{2}$ emissions per unit of energy produced on a life cycle basis (Möllersten et al. 2003)

Extraction and production of esters from oilseeds. Oilseeds, like rapeseed, can be extracted and converted to esters and are well suited to replace diesel. Rapeseed production and subsequent esterification and distribution is established technology in Europe. Significant quantities of Rapeseed MethylEster (RME) are produced in the EU (concentrated in Germany, France and to a lesser extent in Austria and Italy). RME however, requires substantial subsidies to compete with diesel, also on the longer term. Subsidies in Europe generally consist of a combination of farm subsidies (e.g. for producing non-food crops) and tax exemption of the fuel itself. The latter implies about a factor of 3-4 subsidy compared to conventional diesel or gasoline production costs (see also Table III). Key drivers for the implementation of RME schemes are rural employment and the flexible nature of the crop because it can easily replace conventional food crops when desired. Energy balances of RME fuel chains are less favourable when compared to perennial crops and net energy production per hectare is lower (Kaltschmitt et al. 1996; Biewinga et al. 1996). Energy balances and economic performance can be improved to some extent, particularly by using straw for efficient heat and power production (IEA 1994; Hamelinck and Faaij 2004), but not to such an extent that RME can compete with gasoline and diesel.

\section{Markets for Bio-Energy}

Absolutely crucial for the success of bio-energy systems is their economic performance. Biomass is a competitive alternative in many situations, but this is generally observed where cheap, or even negative costs biomass residues or wastes are available. In order to make large scale bio-energy use (especially from dedicated biomass crops) competitive with fossil fuels, the conversion technologies, biomass production, as well as the total bio-energy systems, require further development and optimisation. Various technological possibilities were summarized in Section 2. Table IV gives a global overview of the main markets on short and longer term for biomass use for energy.

\subsection{HEAT, POWER AND FUELS FROM BIOMASS; KEY MARKETS}

With biomass prices of about 2U\$/GJ state of the art combustion technology at a scale of 40-60 MWe can result in Costs of Electricity (COE) of around U\$ ct 56/kWh produced (DOE 1998; Dornburg and Faaij 2001). (Solantausta et al. 1996). Co-combustion, particularly at efficient coal fired power plants, can obtain similar 


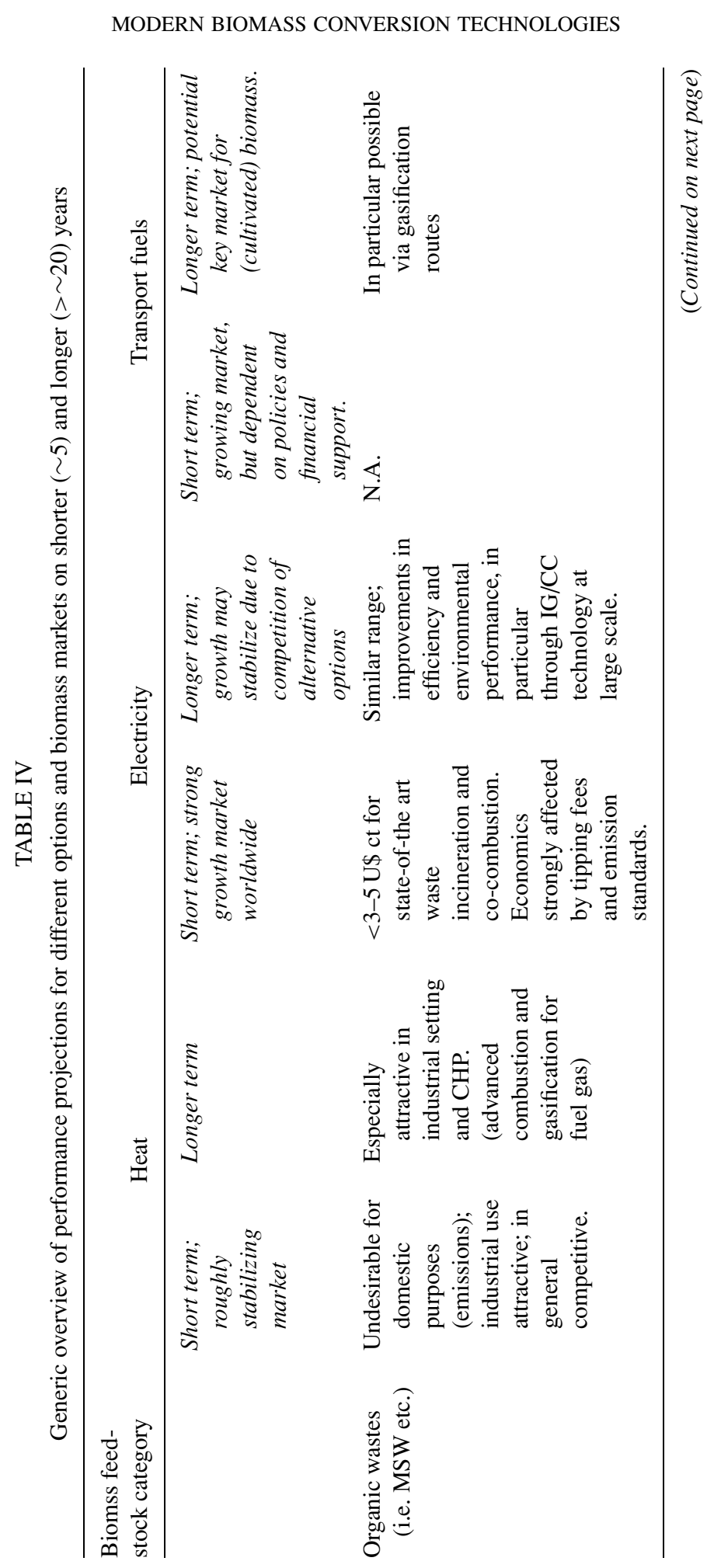




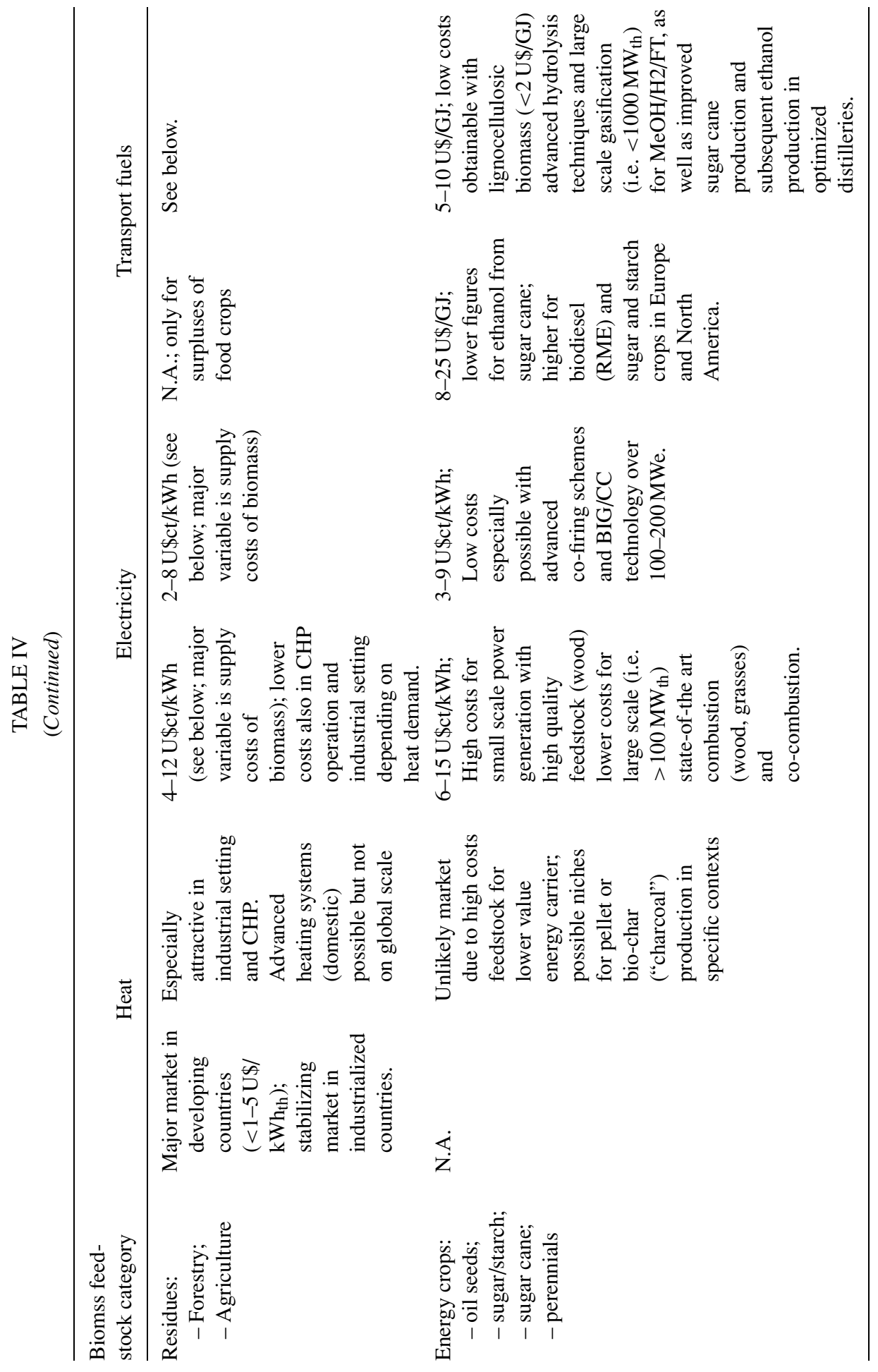


or lower cost figures, largely depending on the feedstock costs. When BIG/CC technology becomes available commercially, COE could drop further to about 3$4 \mathrm{U} \$ \mathrm{ct} / \mathrm{kWh}$, especially due to higher electrical efficiencies. For larger scales (i.e. over $100 \mathrm{MWe}$ ) cultivated biomass will be able to compete fully with fossil fuels in many situations. The benefits of lower specific capital costs and increased efficiency certainly outweigh the increase in costs and energy use for transport for considerable distances once a reasonably well developed infrastructure is in place (Marrison and Larson 1995; Dornburg and Faaij 2001).

Decentralised power (and heat) production is generally more expensive, but better suited for off-grid applications. The costs that could ultimately be obtained with e.g. gasifier/diesel systems are still unclear and depend strongly on what emissions and fuel quality are considered acceptable. Combined Heat and Power generation is generally attractive when heat is required with high load factors.

As discussed in Section 1, production of heat and electricity dominate current bio-energy use. At present, the main growth markets for bio-energy are the European Union, Central and Eastern Europe and South East Asia (Thailand, Malaysia, Indonesia), especially with respect to efficient power generation from biomass wastes and residues. Two key industrial sectors for application of state-of-the-art biomass combustion (and potentially gasification) technology for power generation are the paper and pulp sector and cane based sugar industry worldwide.

In most European countries heat production from biomass has stagnated somewhat (unless in CHP applications) (Hamelinck et al. 2002). Bio-energy developments in North America (US, Canada) has stalled in recent years, in particular due to political developments, the one exception being ethanol production linked to the corn and grain production and processing industries. Table IV gives a broad overview of the perspectives for various markets combined with main biomass resources on short and longer term. Key points are:

- In traditional bio-energy use, heat for cooking and space heating are crucial. It is not expected that the traditional use of biomass will diminish in coming decades, since traditional biomass use is often interlinked with poverty and underdevelopment, which prove difficult problems to solve. Nevertheless, modernizing bio-energy use for the poorer part of populations is an essential component of sustainable development schemes in many countries. This creates opportunities and major markets for example for improved stoves, production of high quality fuels for cooking (e.g. biofuel based such as ethanol and fischer-tropsch liquids) with considerable efficiency and health advantages. Furthermore, biogas, e.g. produced with digestors on village level, prove very effective in various countries (such as China and India) in solving waste treatment problems and supplying high quality energy carriers (clean gas and power when used in gas engines) along with hygienic bio-fertilizers.

- Commercial heat production from biomass stalls in most countries with significant biomass utilization. Reliable technology (e.g. gasification, advanced stoves, etc.) are commercially available for many applications (industrial, 
district and domestic heating), but profitability of power generation (or CHP) seems better in most current markets. Especially, for specific industrial applications heat production from biomass seems most attractive.

- Power generation from biomass by advanced combustion technology and cofiring schemes is at present the real growth market worldwide. Mature, efficient and reliable technology is available to turn biomass into power. In various markets the average scale of biomass combustion schemes rapidly increases due to improved availability of biomass resources and the economic advantages of economies of scale of conversion technology. It is also in this field that competitive performance compared to fossil fuels is possible where lower cost residues are available. This is in particular true for co-firing schemes, where investment costs can be minimal. Specific (national) policies (such as carbon taxes, renewable energy support, e.g. by direct investment subsidies or feed-in tariffs) accelerate this development. Gasification technology (integrated with gas turbines/combined cycles) offers even better perspectives for power generation from biomass on medium term and can make power generation from energy crops competitive in many areas in the world once this technology has been proven on commercial scale. Gasification (in particular larger scale CFB concepts) also offers excellent possibilities for co-firing schemes.

\subsection{PRODUCTION OF LIQUID AND GASEOUS FUELS FROM BIOMASS}

Table III gave a compact summary of estimates for costs of various fuels that can be produced from biomass. A distinction is made between performance levels on the short and on the longer term. Generally spoken, the economy of 'traditional' fuels like Rapeseed MethylEsther and ethanol from starch and sugar crops in moderate climate zones is poor and unlikely to reach competitive price levels even in the longer term. Also, the environmental impacts of growing annual crops are not as good as perennials because per unit of product considerable higher inputs of fertilizers and agrochemicals are needed (see e.g. Biewinga et al. (1996) and Kaltschmitt et al. (1996)). In addition, annual crops on average need better quality land than perennials to achieve good productivities. Perennial crops can also be grown on marginal lands, thereby achieving potential other key benefits such as soil quality improvement.

A key exception under 'conventional' biofuels is production of ethanol from sugar cane in tropical regions where good soils are available, which proves currently a competitive system in the Brazilian context and some other countries. For countries where sugar cane production is feasible, commercially available technology allows for production of relatively low cost ethanol. Brazilian experience shows that ethanol production competitive with gasoline is possible at current oil prices (Rosillo-Calle 1998; Goldemberg et al. 2004). Ethanol production capacity based on sugar cane is increasing in some African, several Latin American and Asian 
(most notably India and China) countries. Furthermore, better use of cane residues (e.g. for power generation or use via hydrolysis processes) can further improve the performance of cane based ethanol production.

But it is production of methanol (and DME), hydrogen, Fischer-Tropsch liquids and ethanol produced from ligno-cellulosic biomass that offer much better perspectives and competitive fuel prices in the longer term (e.g. around 2020). Partly, this is because of the inherent lower feedstock prices and versatility of producing ligno-cellulosic biomass under varying circumstances. Hoogwijk et al., indicated that on longer term perennial cropping systems could supply a few hundred EJ by mid-century in a competitive cost range between 1-2 Euro/GJ. Furthermore, as discussed in this paper, the (advanced) gasification and hydrolysis technologies under development have the inherent improvement potential for efficient and competitive production of fuels (sometimes combined with co-production of electricity).

An important point is also that when the use of such 'advanced' biofuels (especially hydrogen and methanol) in advanced hybrid or Fuel Cell Vehicles (FCV's) is considered, the overall chain ('tree-to-tyre') efficiency can drastically improve compared to current bio-diesel or maize or cereal derived ethanol powered Internal Combustion Engine Vehicles; the effective number of kilometres that can be driven per hectare of energy crops could go up with a factor of 5 (from a typical current $20,000 \mathrm{~km} / \mathrm{ha}$ for a middle class vehicle run with RME up to over $100,000 \mathrm{~km} / \mathrm{ha}$ for advanced ethanol in an advanced hybrid or FCV (Faaij and Hamelinck 2002)). Note though, that the exception to this performance is sugar cane based ethanol production; in Brazil the better plantations yield some 8000 litre ethanol/ha yr, or some $70,000 \mathrm{~km} / \mathrm{yr}$ for a middle class vehicle. In the future, those figures can improve further due to better cane varieties, crop management and efficiency improvement in the ethanol production facilities (Damen 2001).

Furthermore, FCV's (and to a somewhat lesser extent advanced hybrids) offer the additional and important benefits of zero or near zero emission of compounds like $\mathrm{NO}_{x}, \mathrm{CO}$, hydrocarbons and small dust particulates, which are to a large extent responsible for poor air quality in most urban zones in the world.

Biomass derived transportation fuels currently represent a modest $0.5 \mathrm{EJ}$ (or less than $1 \%$ ) of total bio-energy use worldwide (largely covered by ethanol production from sugar and starch crops). But it is especially in this field that global interest is growing, in Europe, Brazil, North Amercia and Asia (most notably Japan, China and India). Four main drivers explain this growing interest:

1. The transport sector is particularly difficult to tackle in terms of GHG emission reductions; biomass is the only option for supplying (liquid) carbon neutral hydrocarbons.

2. The strategic importance of reducing the dependency on oil, imported from a declining number of exporting countries that experience political instability, is growing as is concern that global oil production may peak sooner than 
previously expected; transport fuels are the by far the most important product produced from mineral oil.

3. Technological developments offer clear perspectives of competitive and efficient production of biofuels from biomass, most notably ethanol via hydrolysis and fermentation techniques and fuels such as Fischer-Tropsch, methanol, DME and hydrogen via gasification. Sugar cane based ethanol production in tropical regions already provides a competitive alternative and ethanol production from this source is growing rapidly.

4. In addition, in the medium term (e.g. after 2020), biomass use for transport fuels may prove to become a more effective way to reduce GHG emissions using biomass than power generation. This can be explained by the partly observed and partly expected reduction in carbon intensity of power generation due to large scale penetration of wind energy, increased use of highly efficient natural gas fired Combined Cycles and deployment of $\mathrm{CO}_{2}$ capture and storage (in particular at coal fired power stations).

In Europe, policy targets are likely to create a major push for biofuels and largescale demonstration, e.g. of Fischer-Tropsch liquid production via gasification of biomass, is likely in the foreseeable future (e.g. before 2010) (EC 2001). Various European countries have shown interest in moving in this direction and serious demonstration activities are being undertaken in Germany and Sweden. Crucial for the economic feasibility of such schemes is their application on large-scale (i.e. over $1000 \mathrm{MW}_{\text {th }}$ ). Related development and investment risks (also concerning a secure supply of biomass) are therefore considerable. Ethanol production from ligno-cellulosic biomass offers similar perspectives as well as technological and development challenges. RD\&D efforts in developing advanced ethanol production technology (including hydrolysis techniques) are significant and various demonstration projects are being carried out (Sweden, US) that may pave the way to large scale commercial use of this technology before 2020 or so.

As discussed, inherent to the advanced conversion concepts, it is relatively easy to capture (and subsequently store) a significant part of the $\mathrm{CO}_{2}$ produced during conversion at relatively low additional costs. This is possible for ethanol production (where partially pure $\mathrm{CO}_{2}$ is produced) and in particular for gasification concepts. Production of syngas (both for power generation and for fuels) in general allows for $\mathrm{CO}_{2}$ removal prior to further conversion. For FT production about half of the carbon in the original feedstock (coal, biomass) can be captured prior to the conversion of syngas to FT-fuels. This possibility allows for carbon neutral fuel production when mixtures of fossil fuels and biomass are used and negative emissions when biomass is the dominant or sole feedstock. Flexible new conversion capacity will allow for multiple feedstock and multiple output facilities, which can simultaneously achieve low, zero or even negative carbon emissions. Such flexibility may prove to be essential in a complex transition phase of shifting from large scale fossil fuel use to a major share of renewables and in particular biomass. The possibility of achieving negative carbon emissions may prove a crucial "back-stop" technology 
when climate change develops at a more rapid pace than so far considered and very rapid emission reductions are strived for.

\section{Closing Remarks}

From a regional or national focus in the eighties and nineties, biomass and bioenergy is increasingly becoming an international matter. Biomass markets are developing into international markets and international trade of biomass and biomass derived energy carriers is on the rise (IEA Task 40 2005). Furthermore, certificate and emission trading as well as projects realized as under the Clean Development Mechanism or as Joint Implementation activity make it more and more difficult to maintain very specific national policies. The recent $\mathrm{EC}$ biofuel directive is an interesting example of a pan-European target that potentially has important consequences for a European bio-energy market, both for production of biomass feedstock and high quality transport fuels. Similar arguments hold for technology developments and the RDD\&D trajectories needed to commercialize more advanced, competitive and efficiency conversion capacity in particular for production of electricity and fuels (Faaij 2004).

Biomass is one of the renewable energy sources capable of making a large contribution to the future worlds' energy supply. Although the actual role of bioenergy will depend on its competitiveness with fossil fuels and on agricultural policies worldwide, it seems realistic to expect that the current contribution of bio-energy of 40-55 EJ per year will increase considerably. A range from 200$300 \mathrm{EJ}$ may be observed looking well into this century, making biomass a more important energy supply option than mineral oil today.

A key issue for bio-energy is that its use should be modernized to fit into a sustainable development path. Especially promising are the production of electricity via advanced conversion concepts (i.e. gasification and state-of-the-art combustion and co-firing) and modern biomass derived fuels like methanol, hydrogen and ethanol from ligno-cellulosic biomass, which can reach competitive cost levels within 1-2 decades (partly depending on price developments with petroleum). Sugar cane based ethanol production already provides a competitive biofuel production system in tropical regions and further improvements are possible. Flexible energy systems, in which biomass and fossil fuels can be used in combination, could be the backbone for a low risk, low cost and low carbon emission energy supply system for large scale supply of fuels and power and providing a framework for the evolution of large scale biomass raw material supply systems. The gasification route offers special possibilities to combine this with low cost $\mathrm{CO}_{2}$ capture (and storage), resulting in concepts that are both flexible with respect to primary fuel input as well as product mix and with the possibility of achieving zero or even negative carbon emissions. Prolonged RD\&D efforts and biomass market development, consistent policy support and international collaboration are essential to achieve this. 


\section{References}

Biewinga, E.E. and van der Bijl, G.: 1996, 'Sustainability of energy crops in Europe, a methodology developed an applied', Centre for Agriculture and Environment, CLM 234-1996, Utrecht, February.

Braber, K.: 1995, 'Anaerobic digestion of municipal solid waste: A modern waste disposal option on the verge of breakthrough', Biomass and Bioenergy 9(1-5), 365-376.

Bridgewater, A.V.: 1998, 'The status of fast pyrolysis of biomass in Europe', In Proceedings of the 10th European Biomass Conference and Technology Exhibition, Wurzburg, Germany, pp. 268271.

Broek, R., van den, A. Faaij, and van Wijk, A.: 1996, 'Biomass combustion power generation technologies', Biomass and Bioenergy 11(4), 271-281.

Calis, H.P., Haan, J.P., Peppink, G., Boerigter, H., Van der Drift, B., Venderbosch, R.J., Faaij, A.P.C. and Van den Broek, R.: 2003, 'Technical and economic feasibility of large scale synthesis gas production in the Netherlands from imported biomass feedstock - a Strategic Decision Analysis study', Report prepared by: Shell Global Solutions International B.V., Energy Research Center of the Netherlands, Biomass Technology Group B.V., Department of Science, Technology and Society - Utrecht University, Ecofys B.V., sponsored by the Agency for Research in Sustainable Energy (SDE project number P2001-008), p. 50.

Celik, F., Larson, E.D. and Williams, R.H.: 2004, 'Transportation fuel from coal with low $\mathrm{CO}_{2}$ emissions', In Proceedings of the 7th International Conference on Greenhouse Gas Control Technologies, Vancouver, BC, Canada, 5-9.

Commission of the European Communities: 2001, 'Communication from the Commission to the European Parliament, the Council, the Economic and Social Committee and the Committee of the Regions on alternative fuels for road transportation and on a set of measures to promote the use of biofuels', COM, p. 547, Brussels.

Consonni, S. and Larson, E.D.: 1994, 'Biomass-gasifier/aeroderivative gas turbine combined cycles, part A: technologies and performance modelling', Prepared for Cogen Turbo Power '94, The American Society of Mechanical Engineers' 8th congress \& exposition on gas turbines in cogeneration and utility, industrial and independent power generation, Portland, Oregon, 25-27.

Consonni, S. and Larson, E.D.: 1994, 'Biomass-gasifier/aeroderivative gas turbine combined cycles, part B: performance calculations and economic assessment', Prepared for Cogen Turbo Power '94, The American Society of Mechanical Engineers' 8th congress \& exposition on gas turbines in cogeneration and utility, industrial and independent power generation, Portland, Oregon, 2527.

Damen, K.: 2001, 'Future prospects for biofuel production in Brazil - a chain analysis comparison of ethanol from sugarcane and methanol from Eucalyptus in Sao Paulo State', Department of Science, Technology \& Society, Utrecht University, NW\&S-E-2001-31, p. 68.

Dornburg, V. and Faaij, A.: 2001, 'Efficiency and economy of wood-fired biomass energy systems in relation to scale regarding heat and power generation using combustion and gasification technologies', Biomass and Bioenergy 21(2), 91-108.

Elliott, P. and Booth, R.: 1993, 'Brazilian biomass power demonstration project', Special project brief, Shell, London.

Faaij, A.: 2004, 'Bio-energy in Europe: Changing technology choices' (Energy Policy; Special on Renewable Energy in Europe, in Press, available on line).

Faaij, A., Hekkert, M., Worrell, E. and van Wijk, A.: 1998, 'Optimization of the final waste treatment system in the Netherlands', Resources, Conservation and Recycling (22), 47-82.

Faaij, A., van Ree, R., Waldheim, L., Olsson, E., Oudhuis, A., van Wijk, A., Daey Ouwens, C., and Turkenburg, W.: 1997, 'Gasification of biomass wastes and residues for electricity production', Biomass and Bioenergy 12(6). 
Faaij, A., Meuleman, B. and Van Ree, R.: 1998, 'Long term perspectives of BIG/CC technology, performance and costs', Department of Science, Technology and Society, Utrecht University and the Netherlands Energy Research Foundation (ECN), report prepared for NOVEM (EWAB 9840).

Faaij, A. and Hamelinck, C.: 2002, 'Long term perspectives for production of fuels from biomass; Integrated assessment and RD\&D priorities', Paper prepared for: The 12th European Conference on Biomass for Energy, Industry and Climate Protection, Amsterdam, the Netherlands, 17-21.

Hamelinck, C.N.: 2004, 'Outlook for advanced biofuels', Ph.D.-thesis, Copernicus Institute, Utrecht University, p. 232.

José Goldemberg, Suani Teixeira Coelho, Plinio Mário Nastari and Oswaldo Lucon: 2004, 'Ethanol learning curve - the Brazilian experience', Biomass and Bioenergy 26(3) 301-304.

Hamelinck, C.N. and Faaij, A.: 2002, 'Future prospects for production of methanol and hydrogen from biomass', Journal of Power Sources 111(1), 1-22.

Hamelinck, C., Faaij, A., den Uil, H. and Boerrigter, H.: 2004, 'Production of FT transportation fuels from biomass; technical options, process analysis and optimisation and development potential', Energy, The International Journal 29(11), 1743-1771.

Carlo N. Hamelinck, Geertje van Hooijdonk and André P.C. Faaij: 2004, 'Future prospects for the production of ethanol from ligno-cellulosic biomass', Biomass and Bioenergy (In Press).

Harmelinck, M., Voogt, M., Joosen, S., de Jager, D., Palmers, G., Shaw, S. and Cremer, C.: 2002, 'PRETIR, Implementation of Renewable Energy in the European Union until 2010', Report executed within the framework of the ALTENER programme of the European Commission, DG-TREN. ECOFYS BV, 3E, Fraunhofer-ISI, Utrecht, the Netherlands, 2002+various country reports.

Hoogwijk, M., Faaij, A., van den Broek, R., Berndes, G., Gielen, D. and Turkenburg, W.: 2003, 'Exploration of the ranges of the global potential of biomass for energy', Biomass and Bioenergy 25(2), 119-133.

Hoogwijk, M., Faaij, A., Eickhout, B., de Vries, B. and Turkenburg, W.: 2005, 'Global potential of biomass for energy from energy crops under four GHG emission scenarios Part A: The geographical potential' (accepted for publication in the Journal: Biomass and Bioenergy, 2005).

Hoogwijk, M., Faaij, A., de Vries, B. and Turkenburg, W.: 'Global potential of biomass for energy from energy crops under four GHG emission scenarios Part B: The economic potential' (submitted for publication in the Journal: Global Environmental Change).

Hillring, B.: 2002, 'Rural development and bioenergy - experiences from 20 years of development in Sweden', Biomass and Bioenergy 23(6), 443-451.

International Energy Agency: 1994, 'Biofuels', Energy and Environment Policy Analysis Series, OECD/IEA, Paris.

International Energy Agency: 2004, 'Biofuels for transport - an international perspective', Office of Energy Efficiency, Technology and $R \& D$, OECD/IEA, Paris.

IEA Task 40: 2005, Sustainable International Bio-energy Trade, under the IEA Bio-energy Agreement: www.fairbiotrade.org.

De Jager, Faaij, A. and Troelstra, W.P.: 1998, 'Cost-effectiveness of transportation fuels from biomass', ECOFYS, Dept. Of Science, Technology and Society, Utrecht University, Innas B.V., Report prepared for NOVEM (EWAB rapport 9830).

Kaltschmitt, M., Reinhardt, G.A. and Stelzer, T.: 1996, 'LCA of biofuels under different environmental aspects', Institut für Energiewirtschaft und Rationelle Energieanwendung (IER) Universität Stuttgart.

Kaltschmitt, M., Rosch, C. and Dinkelbach, L. (eds.): 1998, 'Biomass Gasification in Europe', Institute of Energy Economics and the Rational Use of Energy (IER), University of Stuttgart. Report prepared for the European Commission, DG XII, EUR 18224.

Loo, van, S. and Koppjan, J. (eds.): 2002, Handbook Biomass Combustion and Co-firing, Twente University Press, Enschede, the Netherlands. 
Lynd, L.R.: 1996, 'Overview and evaluation of fuel ethanol from lignocellulosic biomass: Technology, economics, the environment and policy', Annual Review Energy Environment 21, 403465.

Marrison, C.I. and Larson, E.D.: 1995, Cost versus scale for advanced plantation-based biomass energy systems in the US; EOA Symposium on Greenhouse Gas Emissions and Mitigation Research, Washington D.C., 27-29.

Meuleman, B. and Faaij, A.: 1999, 'Overview of Co-combustion options for coal fired power plants', report prepared within the framework of the JOULEIII COBIOCOWA project Dept. of Science, Technology and Society, Utrecht University.

Kenneth Möllersten, Jinyue Yan and Jose R. Moreira: 2003, 'Potential market niches for biomass energy with $\mathrm{CO}_{2}$ capture and storage - Opportunities for energy supply with negative $\mathrm{CO}_{2}$ emissions', Biomass and Bioenergy 25(3), 273-285.

Möllersten, K., Yan, J. and Westermark, M.: 2003, 'Potential and cost-effectiveness of $\mathrm{CO}_{2}$ reductions through energy measures in Swedish pulp and paper mills', Energy 28(7), 691-710.

Morris, M., Waldheim, L., Faaij, A. and Stahl, K.: 2005, 'Status of large-scale biomass gasification and prospects', in Handbook Biomass Gasification, Kurkela, Bridgewater, Knoef (eds.), (forthcoming).

Naber, J.E., Goudriaan, F. and Louter, A.S.: 1997, 'Further development and commercialisation of the small scale Hydro-Thermal Upgrading Process for Biomass Liquefaction', in Proceedings of the Thrid Biomass Conference of the America's. Montreal.

Nikolaisen, L. (ed.) et al.: 1998, 'Straw for Energy Production', Centre for Biomass Technology, Denmark, (available at: http://www.videncenter.dk).

Ogden, J.M., Steinbugler, M.M. and Kreutz, T.G.: 1999, 'A comparison of hydrogen, methanol and gasoline as fuels for fuel cell vehicles: Implications for vehicle design and infrastructure development', Journal of Power Sources 79, 143-168.

Rosillo-Calle, F. and Cortez, L.A.B.: 1998, 'Towards Pro-Alcool II - a review of the Brazilian bioethanol programme', Biomass and Bioenergy 14(2), 115-124.

Rodriguez, M., Faaij, A. and Walter, A.: 2003, 'Techno-economic analysis of co-fired Biomass Integrated Gasification/Combined Cycle systems with inclusion of economies of scale', Energy, The International Journal 28(12), 1229-1258.

Serup, H. (ed.) et al.: 1999, 'Wood for Energy production', Centre for Biomass Technology, Denmark (available at: http://www.videncenter.dk).

Smeets, E., Faaij, A. and Lewandowski, I.: 2004, 'A quickscan of global bio-energy potentials to 2050 - an analysis of the regional availability of biomass resources for export in relation to underlying factors', Report prepared for NOVEM and Essent, Copernicus Institute - Utrecht University, NWS-E-2004-109, p.67 + Appendices.

Solantausta, Y., Bridgewater, T. and Beckman, D.: 1996, 'Electricity production by advanced biomass power systems', VTT Technical Research Centre of Finland, Espoo, Finland (report no. 1729).

Stassen, H.E.: 1995, 'Small scale biomass gasification for heat and power production: A global review', World Bank Technical paper number 296, Energy Series, Washington D.C.

Turkenburg, W.C. (Convening Lead Author), Faaij, A. (Lead Author), et al.: 2000, 'Renewable Energy Technologies', Chapter 7 of the World Energy Assessment of the United Nations, UNDP, UNDESA/WEC, Published by: UNDP, New York.

Tijmensen, M.J.A., Faaij, A.P.C., Hamelinck, C.N. and van Hardeveld, M.R.M.: 2002, 'Exploration of the possibilities for production of Fischer Tropsch liquids via biomass gasification', Biomass and Bioenergy $\mathbf{2 3}(2), 129-152$.

US Department of Energy, Office of Utility Technologies: 1998, Renewable Energy Technology Characterizations, Washington DC, USA.

Williams, R.H. and Larson, E.D.: 1996, 'Biomass gasifier gas turbine power generating technology', Biomass and Bioenergy 10, 149-166. 
Williams, R.H., Larson, E.D., Katofsky, R.E. and Chen, J.: 1995, 'Methanol and hydrogen from biomass for transportation, with comparisons to methanol and hydrogen from natural gas and coal', Centre for Energy and Environmental Studies, Princeton University, reportno. 292.

Wyman, C.E., Bain, R.L., Hinman, N.D. and Stevens, D.J.: 1993, 'Ethanol and methanol from cellulosic biomass', in Renewable Energy, Source for Fuels and Electricity, Island Press, Washington DC. 